Article - Biological and Applied Sciences

\title{
Development of an Extraction Protocol for Fetal Sexing from the Fourth Week of Gestation by Real Time PCR
}

Edwin José Torres de Oliveira ${ }^{1,2}$
https://orcid.org/0000-0002-6244-2846

Ana Paula Maluf Rabacow ${ }^{1,3}$

https://orcid.org/0000-0002-3686-1668

Bruno Pereira de Figueiredo 4

https://orcid.org/0000-0002-5504-7506

Raíssa Borges Ishikawa ${ }^{1}$

https://orcid.org/0000-0002-7113-209X

Lucas Roberto Pessatto ${ }^{1,2}$

https://orcid.org/0000-0002-5433-8563

Bruno Ivo Pelizaro ${ }^{1}$

https://orcid.org/0000-0002-1331-5605

Helder Pereira de Figueiredo ${ }^{4}$

https://orcid.org/0000-0003-4326-6645

Rodrigo Juliano Oliveira ${ }^{1,2,3}$

https://orcid.org/0000-0003-3514-3346

${ }^{1}$ Federal University of Mato Grosso do Sul (UFMS), Stem Cell, Cell Therapy and Toxicological Genetics Research Centre (CeTroGen), Campo Grande, Mato Grosso do Sul, Brazil; ${ }^{2}$ State University of Londrina (UEL), Graduate Programme in Genetics and Molecular Biology, Department of General Biology, Londrina, Paraná, Brazil; ${ }^{3}$ Federal University of Mato Grosso do Sul (UFMS), Graduate Programme in Health and Development in the Central-West Region, School of Medicine (FAMED), Campo Grande, Mato Grosso do Sul, Brazil; ${ }^{4}$ Institute of Scientific Expertise Campo Grande, Mato Grosso do Sul, Brazil.

Received: 2018.07.24; Accepted: 2019.07.08.

*Correspondence: rodrigo.oliveira@ufms.br; Tel.: +55 (67) 3345-7671, Fax: +55 (67) 3345-7190 (R.J.O.). 


\title{
HIGHLIGHTS
}

- Fetal sexing by Real-Time PCR technique.

- Efficient in-house method for extracting fetal DNA in maternal peripheral blood.

- Protocol with sufficient sensitivity to truly identify the fetus gender.

- In-house method based on guanidine thiocyanate and magnetic bead.

\begin{abstract}
Low number of fetal cells in maternal blood limited the use of fetal materials in diagnostic and clinical applications. This research developed a technology which allowed the extraction of fetal DNA by a non-invasive method that offers no risk to the mother or fetus. A total of 132 pregnant women participated in this inquiry. The DNA extraction was performed employing an in-house method based on guanidine thiocyanate and magnetic bead. For the amplification it was used the Quantifier $\mathrm{Y} \mathrm{Kit}{ }^{\mathrm{TM}}$. The fetal sexing analysis of the 132 pregnant women were $100 \%$ in agreement with the ultrasound. Sensitivity and specificity for detection of $Y$ chromosome sequences was possible using Real-Time Polymerase Chain Reaction since the 4th week of gestation. This non-invasive early determination could be employed in fetal gender and also to be extended to detection of genetic diseases in the shortest possible time avoiding invasive methods that puts the fetus at risk.
\end{abstract}

Keywords: Fetal-sexing; DNA extraction; rtPCR.

\section{INTRODUCTION}

The prenatal diagnosis for genetic diseases appeared in the early 1960's from the possibility of analyzing the amniotic fluid cells to evaluate the fetal chromosomal constitution [1]. Currently, this test is part of the gestational routine for the investigation of several diseases and when changes are detected, the pregnant women are referred for specialized medical follow-up [2]. Diagnostic techniques used in prenatal care can be divided into invasive and non-invasive techniques [3]. The invasive tests are performed by collecting the biological material originated from the result of the pregnancy, such as amniotic fluid and chorionic villi. The analysis of these materials makes it possible to diagnose cystic fibrosis and chromosomal abnormalities, such as Turner's syndrome [4].

The disadvantage of invasive tests is the risk to the fetal integrity inherent to collection procedures that causes fetal death in about $1 \%$ of cases [5]. On the other hand, there are non-invasive techniques that do not present risks to the life of the fetus or the pregnant woman.

Ultrasonography is an example of a noninvasive test. This test evaluates the fetal age through the measurements of the fetus, besides allowing the detection of multiple pregnancies and morphological alterations (malformations) [6]. However, this examination is limited and therefore several researchers work on the development of noninvasive techniques for diagnosis of diseases during the gestational period. In this context, molecular biology is an important tool since it allows the detection of mutations through the analysis of fetal genetic material, which can be obtained by maternal peripheral blood by venipuncture which, despite being an invasive technique, it offers minimal risks to the pregnant woman and the fetus [7]. Currently, several tests can be performed using free fetal DNA, such as identification of blood systems [8], identification of genetic diseases caused by point mutation such as sickle cell anemia, thalassemia and cystic fibrosis, and fetal sexing [9-11]. In the last case, this method consists of $\mathrm{Y}$ chromosome detection, by Real-Time Polymerase Chain Reaction (qPCR), and has as a greater challenge to guarantee a reliable result when estimating the sex of the fetus. Therefore, the objective of the present study was to describe 
a standardized protocol with sufficient sensitivity to truly identify the fetus gender from the first weeks of gestation. Fetal sex determination by the fourth week

\section{MATERIAL AND METHODS}

\section{Inclusion criteria}

The data reported in this research were obtained from the record system of the Laboratory of Molecular Genetics of the Institute of Scientific Expertise of Mato Grosso do Sul (IPCMS). During the process of standardization of the fetal sexing test the laboratory invited volunteers who read and signed Informed Consent Term (ICT). The volunteers were divided into a control group composed of non-pregnant women and an experimental group composed of adult women at different gestational ages and who agreed to provide ultrasound for comparison with the genetic results of fetal sexing.

\section{Exclusion criteria}

Pregnant women with less than 4 weeks gestation and those who did not provide the ultrasound results for confirmation were excluded from the pregnant group.

\section{Sample collection}

A total of 136 pregnant women signed the ICT, then the peripheral blood was collected by venipuncture in an EDTA tube. However, four pregnant women did not return with the ultrasound and, the samples were not computed. Therefore, the sample number was composed of 132 pregnant women. After collection, blood was immediately centrifuged for 10 minutes at $3000 \mathrm{rpm}$. Plasma was separated and stored at $-86^{\circ} 19 \mathrm{C}$ until the DNA extraction.

\section{DNA extraction}

The DNA extraction was performed employing an in-house method adapted from the Boom method, 1990, based on guanidine thiocyanate lysis buffer (guanidine thiocyanate $5 \mathrm{~mol} / \mathrm{L}$, Tris HCL $11,2 \mathrm{~g} / \mathrm{L}$, EDTA $7.43 \mathrm{~g} / \mathrm{L}, 7,8 \mathrm{~mL}$ Triton $\mathrm{X}-100$ ) with the $\mathrm{pH}$ adjusted to 6.4 with $\mathrm{NaOH}$. Samples were extracted in triplicate using $200 \mu \mathrm{L}$ of the suspension cell in $200 \mu \mathrm{L}$ of the Lysis Buffer. After homogenizationfor 10 minutes, $50 \mu \mathrm{l}$ of magnetic bead (Nuclisens ${ }^{\circledR}$, bioMérieux) was added and allowed to stand for 10 minutes. Two washes were performed with lysis buffer to remove cell debris by keeping the DNA retained in the beads on a magnetic shelf (Promega ${ }^{\circledR}$ ). Excess of guanidine thiocyanate and salts were withdrawn with $70 \%$ ultrapure alcohol washings. After, the beads were washed with acetone PA and heated for one minute at $31^{\circ} \mathrm{C}$ in dry bath $\mathrm{DB}-\mathrm{HC}$ (Loccus ${ }^{\circledR}$, Brazil). Then, the genetic material was eluted with $30 \mu \mathrm{L}$ TE (Tris-EDTA from bioMérieux®).

\section{DNA quality}

After extraction, the amount of genetic material was analyzed in the spectrophotometer NanoVue ${ }^{\mathrm{TM}}$ Plus (GE Healthcare - Life Sciences ${ }^{\circledR}$ ) and the quality of the DNA were evaluated by the quotient DO260 and DO280. DNA integrity was assessed on $1 \%$ denaturing agarose gel.

\section{Real time PCR (qPCR)}

For the amplification process was used, $20 \mu \mathrm{L}$ of the Quantifier $Y^{\mathrm{TM}}\left(\right.$ ThermoFisher $\left.^{\circledR}\right)$ kit and $5 \mu \mathrm{l}$ of the sample. The Quantifier $Y^{\mathrm{TM}}$ kit has two pairs of probes, being one of an amplification control called IPC (Internal PCR Control) and another of $Y$ chromosome, which generates amplified products of 62 base pairs. The controls used were from the kit (positive) and the negative obtained from DNA extraction from nonpregnant women. The amplification process was performed on StepOne ${ }^{\mathrm{TM}}$ (Applied Biosystems ${ }^{\mathrm{TM}}$ ), equipment with a programmed temperature of $95^{\circ} \mathrm{C}$ for 5 minutes, 40 cycles of $95^{\circ} \mathrm{C}$ for 15 seconds, $60^{\circ} \mathrm{C}$ for 
one minute and $72^{\circ} \mathrm{C}$ for 30 seconds. The results were analyzed in StepOne ${ }^{\mathrm{TM}}$ software version 2.3.

\section{RESULTS}

The extraction technique was efficient to obtain the DNA in sufficient quantities and with adequate degree of purity for amplification reactions in Real Time PCR. The integrity of the extracted genetic material was observed by the presence of single DNA band, without DNA fragmentation. The fetal sexing analysis of the 132 pregnant women were $100 \%$ in agreement with the ultrasound; and $53.79 \%$ of the fetuses were male and $46.21 \%$ female. Regarding gestational age, there was a higher prevalence of pregnant women between 7 and 12 weeks of gestation. The test was sensitive in detecting fetal sex even in the early stages of gestation from the 4th week (Figure 1).

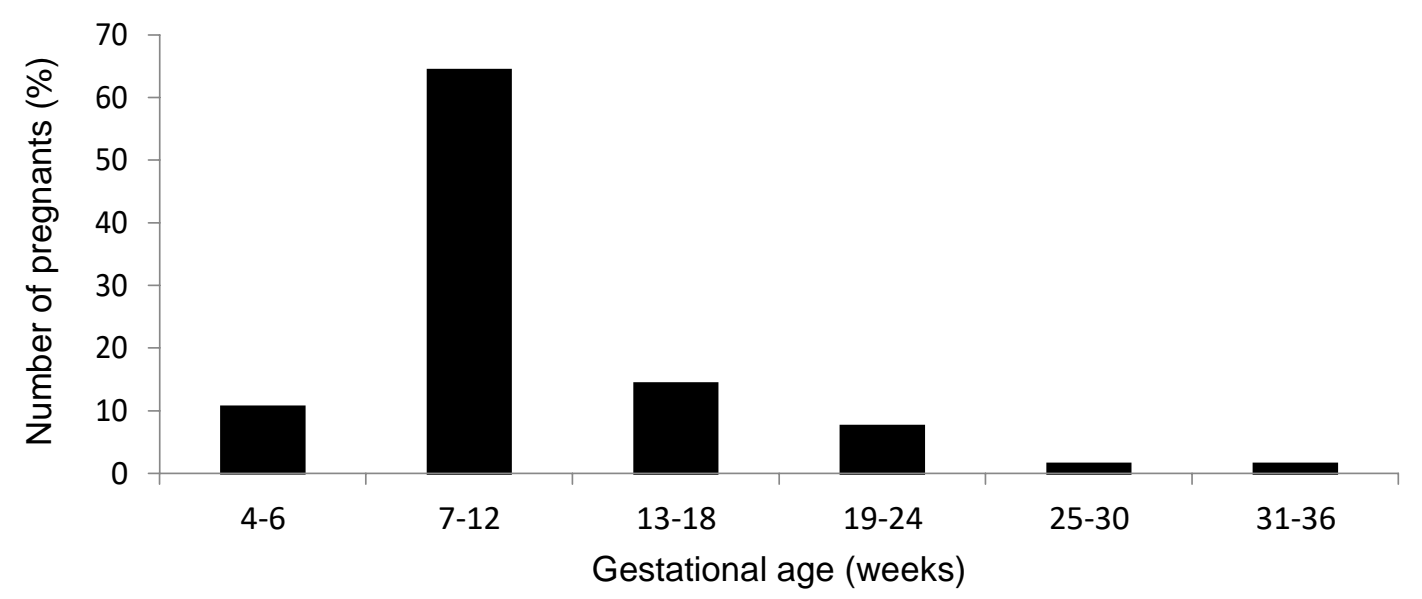

Figure 1. Gestational age of the pregnants (in weeks), submitted to fetal sexing by Real-Time PCR technique.

\section{DISCUSSION}

The present work described an efficient in-house method for extracting fetal DNA in maternal peripheral blood. Several studies have shown that the silica particles might be used in the purification of DNA in a highly concentrated salt environment and Guanidium isothiocyanate (GuSCN) is a powerful chaotropic agent which also plays the deproteinizing role [12]. Adjustments to the original method [13], allowed obtaining a clean and good DNA quality easily amplifiable by PCR. The sensitivity and purity of the extraction method are directly related to obtaining fetal DNA in an amount sufficient for amplification, which is the most challenging step in the method of the standardization process. This finding is corroborated by Johnson et al [30] who reported that the sensitivity for male detection ranges from 31 to $97 \%$ among laboratories and suggested that one reason is the different yields in obtaining DNA. Furthermore, it is considered that the high variability in the sensitivity of the tests may also occur due the low concentrations of fetal DNA in the maternal samples [14-16].

This methodology can also be applied to other genetic detections. Thus, the target gene of the detection becomes another factor that can interfere in the method sensitivity. According to Chitty et al [29], which genotyped the RHD system RHD (Rh blood group, D antigen) using the qPCR technique [17-18], there is a 1.8\% error (16 errors in 865 tests) in samples collected from pregnant women with less than 11 weeks of gestation. Still based on the interference of time in the sensitivity of the test, research indicates that from the 8th week of gestation it is safe to determine the fetal sex by means of the qPCR technique. On the other hand, our results demonstrate that the method used achieved results with $100 \%$ reliability, when compared to ultrasound results, from the 4th week of gestation. This data is a pioneer and had not been reported in any research, in the literature consulted by our group. 
The concentration of fetal DNA in maternal plasma increases with gestational age and the highest point occurs in the last 8 weeks of gestation [19] due to apoptotic fragments of the syncytiotrophoblast and placental lesions [20]. The time between collection and extraction of DNA also interferes with the quality of the test. After collection it is indicated to leave the sample refrigerated at $4^{\circ} \mathrm{C}$ until the time of centrifugation, and when the plasma is obtained, if it is not just after the extraction of the DNA, the plasma must be frozen at temperatures below $-20^{\circ} \mathrm{C}$ [21]. In this context, the logistics process of fetal sexing test standardization may affect the viability of the result.

Considering this technology for a more embracing application than only fetal sexing, it is worth noting its use in the genotyping of the RHD system, in the diagnosis of monogenic diseases, in the detection of Single Nucleotide Polymorphism SNPs [8-22]. Using the Massively Parallel Sequencing MPS technique, which enables the sequencing of millions of DNA molecules and identifies the chromosomal origin of each one of them, researchers have developed noninvasive tests for prenatal detection of chromosome 21 trisomy, [23-24]. Currently, the noninvasive prenatal test can detect several genetic syndromes as Edwards, Patau, chromosome 18 trisomy, chromosome 13, among others positivos [11-25]. However, there is still an uncertainty about the sensitivity of the test, and it is not recommended as a final diagnosis. As discussed, there are several possibilities of using fetal DNA within the medical field, such as predictive medicine and even in performing the genetic linkage test. Popularly known as a DNA test, that analyzes DNA sequences and compares alleles on the profile of individual to verify whether these correspond. During gestation, many patients opt for invasive collection to perform this type of test, exposing mother and fetus to the inherent risks of the collect. For these cases, the use of fetal DNA in maternal plasma is promising, minimizing the risks and deaths resulting from invasive collection [26-28].

The technology presented in this study was able to extract, with quantity and quality, the fetal DNA of the maternal plasma and to determine, from the 4th week of gestation the fetal sex, which allows the application of the extraction described by our group in the execution of clinical tests aimed at the reliable determination of the fetal sex from the 4th week of gestation, as well as new research to evaluate the use of this technique as a tool in the noninvasive prenatal diagnosis of genetic diseases and genetic linkage.

Conflicts of Interest: The authors declare no conflict of interest.

\section{REFERENCES}

1. Boyd PA, Rounding C, Chamberlain P, Wellesley D, Kurinczuk JJ. The evolution of prenatal screening and diagnosis and its impact on an unselected population over an 18-year period. An Int J Obstet Gynaecol. 2012;119:1131-40.

2. Wright CF, Wei Y, Higgins JPT, Sagoo GS. Non-invasive prenatal diagnostic test accuracy for fetal sex using cell-free DNA a review and meta-analysis. Res Notes. 2012;5:476.

3. Newson AJ. Ethical aspects arising from non-invasive fetal diagnosis. Semin Fetal Neonatal Med. 2008;13:103-8.

4. Huszka M. Amniotic fluid microvillar enzyme activity in fetal malformations. Clin Genet. 1990; 340-5

5. Lo YM, Corbetta N, Chamberlain PF, Rai V, Sargent IL, Redman CW, et al. Presence of fetal DNA in maternal plasma and serum. Lancet. 1997;350: 485-7.

6. Ebrashy A, EL Kateb A, Momtaz M, EL Sheikhah A, Aboulghar MM, Ibrahim M, et al. 13-14-week fetal anatomy scan: a 5-year prospective study. Ultrasound Obstet Gynecol. 2010;35: 292-6.

7. Chiu RWK, Akolekar R, Zheng YWL, Leung TY, Sun H, Chan KCA, et al. Non-invasive prenatal assessment of trisomy 21 by multiplexed maternal plasma DNA sequencing: large scale validity study. BMJ. 2011;342:c7401-c7401.

8. Scheffer PG, Ait Soussan A, Verhagen OJHM, Page-Christiaens GCML, Oepkes D, De Haas M, et al. Noninvasive fetal genotyping of human platelet antigen-1a. An Int J Obstet Gynaecol. 2011;118:1392-5. 
9. Yenilmez ED, Tuli AEC. Noninvasive prenatal diagnosis experience in the Çukurova Region of Southern Turkey: Detecting paternal mutations of sickle cell anemia and $\beta$-thalassemia in cellfree fetal DNA using high-resolution melting analysis. Prenat Diagn. 2013;33(11):1054-62.

10. Nasis $O$, Thompson S, Hong $T$, Sherwood M, Radcliffe S, Jackson L, et al. Improvement in sensitivity of allele-specific PCR facilitates reliable noninvasive prenatal detection of cystic fibrosis. Clin Chem. 2004;50:694-701.

11. Taylor-Phillips S, Freeman K, Geppert J, Agbebiyi A, Uthman OA, Madan J, et al. Open accuracy of non-invasive prenatal testing using cell-free DNA for detection of Down, Edwards and Patau syndromes: A systematic review and meta-analysis. BMJ Open. 2016;6(1):e010002.

12. Magloire ABL, Zoa AS, Moukassa D, Touil N, Mestoui O, Khattabi A, et al. Optimization of a manual and rapid Silica - based DNA Extraction Method: Applied to Human papillomavirus detection using fresh Cervical Biopsies Samples. Int J Sci Res Publ. 2015;5:2250-3153.

13. Boom R, Sol CJ, Salimans MM, Jansen CL, Wertheim-van Dillen PM, van der Noordaa J. Rapid and Simple Method for Purification of Nucleic Acids. J Clin Microbiol. 1990;28:495-503.

14. Lo YMD, Lau TK, Chan LYS, Leung TN, Chang AMZ. Quantitative analysis of the bidirectional fetomaternal transfer of nucleated cells and plasma DNA. Clin Chem. 2000;46:1301-9.

15. Zhong XY, Bürk MR, Troeger C, Kang A, Holzgreve W, Hahn S. Fluctuation of maternal and fetal free extracellular circulatory DNA in maternal plasma. Obstet Gynecol. 2000;96:991-6.

16. Müller SP, Bartels I, Stein W, Emons G, Gutensohn K, Köhler M, Legler TJ. The determination of the fetal $D$ status from maternal plasma for decision making on Rh prophylaxis is feasible. Transfusion. 2008;48:2292-301.

17. Zimmermann B, El-Sheikhah A, Nicolaides K, Holzgreve W, Hahn S. Optimized real-time quantitative PCR measurement of male fetal DNA in maternal plasma. Clin Chem. 2005:51:1598-604.

18. Stanghellini I, Bertorelli R, Capone L, Mazza V, Neri C, Percesepe A, et al. Quantitation of fetal DNA in maternal serum during the first trimester of pregnancy by the use of a DAZ repetitive probe. Mol Hum Reprod. 2006;12:587-91.

19. Lo YMD, Tein MSC, Lau TK, Haines CJ, Leung TN, Poon PMK, et al. Quantitative Analysis of Fetal DNA in Maternal Plasma and Serum: Implications for Noninvasive Prenatal Diagnosis. Am J Hum Genet. 1998;62:768-75.

20. Birch L, English CA, O'Donoghue K, Barigye O, Fisk NM, Keer JT. Accurate and robust quantification of circulating fetal and total DNA in maternal plasma from 5 to 41 weeks of gestation. Clin Chem. 2005;51:312-20.

21. Sillence KA, Roberts LA, Hollands HJ, Thompson HP, Kiernan M, Madgett TE, et al. Fetal sex and RHD genotyping with digital PCR demonstrates greater sensitivity than real-time PCR. Clin Chem. 2015;61:1399-407.

22. Nicolaides KH, Syngelaki A, Ashoor G, Birdir C, Touzet G. Noninvasive prenatal testing for fetal trisomies in a routinely screened first-trimester population. Am J Obstet Gynecol. 2012;207(5):374.e1-6.

23. Ehrich M, Deciu C, Zwiefelhofer T, Tynan JA, Cagasan L, Tim R, et al. Noninvasive detection of fetal trisomy 21 by sequencing of DNA in maternal blood: A study in a clinical setting. Am $\mathrm{J}$ Obstet Gynecol. 2011;204(3):205.e1-11.

24. Kim S, Jung H, Han SH, Lee S, Kwon J, Kim MG, et al. An adaptive detection method for fetal chromosomal aneuploidy using cell-free DNA from 447 Korean women. Med Genomics. 2016;9:61.

25. Gil MM, Quezada MS, Revello R, Akolekar R, Nicolaides KH. Analysis of cell-free DNA in maternal blood in screening for fetal aneuploidies: Updated meta-analysis. Ultrasound Obstet Gynecol. 2015;45:249-66.

26. Hromadníková I, Bendukidze N, Mrštinová M, Ivašková E. Analysis of paternal alleles in nucleated red blood cells enriched from maternal blood. Folia Biol (Praha). 2001;47:36-9

27. Wagner J, Dzijan S, Marjanović D, Lauc G. Non-invasive prenatal paternity testing from maternal blood. Int J Leg Med. 2009;123:75-9.

28. Fan HC, Gu W, Wang J, Blumenfeld YJ, El-Sayed YY, Quake SR. Non-invasive prenatal measurement of the fetal genome. Nature. 2012;487:320-4. 
29. Chitty LS, Finning K, Wade A, Soothill P, Martin B, Oxenford K, et al. Diagnostic accuracy of routine antenatal determination of fetal RHD status across gestation: population based cohort study. BMJ. 2014;349:g5243-g5243.

30. Johnson KL, Dukes KA, Vidaver J, LeShane ES, Ramirez I, Weber WD, et al. Interlaboratory Comparison of Fetal Male DNA Detection from Common Maternal Plasma Samples by RealTime PCR. Clin Chem. 2004;50:516-21

(C) 92018 by the authors. Submitted for possible open access publication
under the terms and conditions of the Creative Commons Attribution (CC
BY NC) license (https://creativecommons.org/licenses/by-nc/4.0/). 